\title{
Üniversite Öğrencilerinin Sosyal Medyaya İlişkin Tutumlarının İncelenmesi*
}

\author{
Cemal AKÜZÜM1, Mehtap SARAÇOĞLU² \\ ${ }^{1}$ Doç. Dr., Dicle Üniversitesi Ziya Gökalp Eğitim Fakültesi, cemal.akuzum@dicle.edu.tr \\ ${ }^{2}$ Yrd.Doç.Dr., Sïrt Üniversitesi Eğitim Fakülttesi, mehtapsara@@siirt.edu.tr
}

Bu araștırmada, üniversite öğrencilerinin sosyal medyaya ilișkin tutumlarının çeșitli değișkenler açısından incelenmesi amaçlanmıştır. Tarama türünde betimsel bir çalısma olarak gerçekleştirilen araştırmanın evrenini, 2015-2016 öğretim yllında Dicle Üniversitesi Ziya Gökalp Eğitim Fakültesi’nde öğrenim gören öğrenciler oluşturmaktadır. Örneklemini ise, rastgele yöntemle seçilen farklı bölüm ve sınıflarda öğrenim gören 399 öğrenci oluşturmaktadır. Veri toplama aracı olarak, 4 faktör ve 23 maddeden oluşan "Sosyal Medya Tutum Ölçeği” kullanılmıştır. Çalışmadan elde edilen veriler SPSS (Staistical Package for the Social Sciences) paket programı ile analiz edilmiştir. Araștırma bulguları; öğretmen adaylarının en yüksek düzeyde katılım gösterdikleri boyutun sosyal medyaya ilişkin olumsuz ifadelerin yer aldığ1 "sosyal izolasyon" boyutu olduğu, en düşük düzeyde katıllım gösterdikleri boyutun ise "sosyal yetkinlik" boyutu olduğunu göstermektedir. Günümüz gençliğinin hayatında önemli yer tutan sosyal medyanın daha verimli ve etkili kullanılabilmesi için "Medya Okuryazarlığı" dersinin okulöncesi eğitimden başlayarak yaşam boyu öğrenme sürecinde yer alması ve zorunlu ders olması önerilebilir.

Anahtar Kelimeler: Sosyal medya, yeterlilik, tutum, öğrenci.

\section{Investigation of Attitudes of University Students Towards Social Media}

\begin{abstract}
Investigating attitudes of university students regarding social media from various variables perspective is aimed in this research. Research has been conducted as a survey type descriptive study and the universe of research includes undergraduate students who study at Dicle University Ziya Gokalp Education Faculty in 2015-2016 academic year. Sample is obtained by random sampling method and includes a total of 399 undergraduate students from various departments and grade levels. The "Social Media Attitudes Scale", that consists of 4 factors and 23 items, is used as the data collection tool. Data that is gathered in this research is analyzed by SPSS (Statistical Package of the Social Sciences) program. Research results revealed that teacher candidates show the highest level of acceptance in the "Social Isolation" dimension that includes negative items and teacher candidates show the lowest level of acceptance in the "Social Competence" dimension. It may be suggested that in order to use the social media, that has an important place in the life of today's youth, effectively and efficiently, the "media literacy" course should be included in curricula starting from kindergarden education through lifelong learning process and it should be a compulsory course.
\end{abstract}

Keywords: Social media, qualification, attitude, student.

\section{GİRİ̧̧}

Bilgi ve teknoloji çağı olarak adlandırılan yirmi birinci yüzyılda internet ve bilgi işlem teknolojileri büyük bir hızla değişmekte ve gelişmektedir. Bu değişim eğitim, sosyal, ekonomik ve kültürel yaşamı, kişilerarası etkileşimi ve iletişimi de etkilemektedir. Hayatımızın her alanında varlığını hissettiğimiz internet birçok üretim sürecini etkilediği gibi alışkanlıklarımızı da değiştirmekte ve etkilemektedir. İnsanların temel ihtiyaçlarından biri olan iletişim; Web 1.0, Web 2.0, Web 3.0 şeklinde adlandırılan internetin gelişimiyle, sosyalleşme tercihlerinde de değişiklikler meydana getirerek sosyal medyayı hayatımızın ayrılmaz bir parçası haline getirmiştir. Günümüzde insanlar sosyal medya aracllı̆ıyla fikirlerini veya kendilerine ait içerikleri tüm dünyayla paylaşma imkânına eriştiler. Bu durum iletişimin çeşidini ve yönünü de değiştirmiş oldu.

\footnotetext{
${ }^{*}$ Çalışma, 3rd. International Conference on New Trends in Education'de sözlü bildiri olarak sunulmuştur.
} 
Birinci nesil web araçlarında genellikle yukarıdan aşağıya bir yapının hâkim olmasıyla kullanıcılar pasif konumda olmakla birlikte (Petter, Reich \& Scheuermann, 2005), Web 1.0 araçları insanlar tarafindan arayüzünde oluşturulan sayfalarla internet uygulamalarının olduğu bir mecraydı. Web 2.0 araçları ile aşağıdan yukarıya bir yapı hâkim olmuş ve bu yapıda da kullanıcı, teknik engellerle karşılaşmadan içeriğini yayımlayabildiği gibi sosyal etkileşim ve işbirliği sağlayan servis ve uygulamalardan yararlandığı insan odaklı bir teknoloji olmuştur. Web 3.0 ise, cihazlar arası etkileşimin olacağı internetin kendi kendine üretimlerde bulunacağı internet teknolojisi olarak bilinmektedir (Gökçearslan, 2011).

Tek yönlü bir iletişim olanağı sağlayan Web 1.0'de, kullanıcılar sadece okuyucu olmanın yanı sıra sadece bilgiyi alabilen bir konumdaydılar (Ergenç, 2011). İkinci nesil web araçları ya da sosyal yazılımlar olarak isimlendirilen (D'Souza, 2006) Web 2.0, kavram olarak Web 1.0 teknolojilerinin internet kullanıcılarına sunduklarının aksine içeriğin kullanıcı tarafından oluşturulmasına olanak sağlayan ve internet üzerinden iletişim kuran bireylerin birbirleriyle etkileşiminin ön planda tutulmasını sağlayan teknolojiler bütünü olarak ifade edilebilir (O'Reilly, 2005). Katılımcıların uygulamalarına olanak tanıyan (Eijkman, 2009) WEB 2.0'ın başarısı, kullanıcıları sürekli bağlayan yaratıcı uygulamalarından ileri gelmektedir (Kesselman, 2008). Web 2.0 uygulamaları ile bireyler sürece etkin olarak katılıp, teknik engellerle karşılaşmadan içeriğini yayımlayabildiği, sosyal etkileşim ve işbirliği sağlayan servis ve uygulamalardan yararlandığı bir ortam elde etmiş (Petter, Reich \& Scheuermann, 2005) ve ulaştıkları bilgileri yayınlama ve saklama imkanı elde etmişlerdir. Bu içeriğin yayınlanmasını ise kimi zaman bireysel (bloglarla), kimi zaman birlikte (vikilerle), kimi zaman ses kaydı (podcastlerle) kimi zaman video materyali şeklinde (Vidcastlerle) gerçekleştirmek mümkündür (McLoughlin \& Lee, 2007).

Yeni nesil internet Web 2.0'de ise kullanıcının aktif rol oynadığı, fikirlerini ve deneyimlerini paylaşabildiği, çok yönlü etkileşim içeren sosyal medya kavramı ortaya çıtı. Sosyal medya ilk kez San Fransisco merkezli Guidewire Group'un kurucu ortaklarından Chris Shipley tarafindan kullanılmıştır. Bu kavram, “online” olarak iletişim ve bilgiyi mümkün kılan, katılım ve işbirliğini destekleyen tüm araçları kapsamaktadır (Dewson, Houghton \& Patten, 2008).

Klasik web tabanlı eğitimde sunmaya dayalı tek taraflı bir etkileşim söz konusu iken, Web 2.0 ve buna bağlı olarak da sosyal ağlar paylaşımlı ve çok taraflı bir etkileşim sunmaktadır (Barış, 2011). Web 2.0 teknolojisi, kullanıcılarına içerik yaratma ve bu içeriği paylaşma olanağı sağlamıştır. İçeriği kullanıcılar tarafından yaratılan sosyal medyanın gücü, iletişimin tek-yönlü yayma niteliğinden daha çok karşılıklı etkileşime olanak vermesinden doğmaktadır. Bu durum, kullanıcılara çok yönlü etkileşim kurma, demokratik ve eş düzeyli iletişim ve sosyalleşme imkânı sağlamaktadır.

Bilgi iletişim teknolojilerinin gelişmesinin bir ürünü olan hızlı internet erişiminin hayatımızın her alanında ulaşılabilir konuma gelmesi, sosyal medyayı modern toplumun ayrılmaz bir parçası haline getirmiştir. Sosyal medya, birbirinden bağımsız olarak gelişmiş ve tüketicilerin kendi içeriklerini yansıtabilmelerini ve başkalarıyla paylaşmalarını sağlayan çevrimiçi uygulamalardır (Gülsoy, 2009). İki binli yıllardan sonra hızla gelişen ve hayatımızın ayrılmaz bir parçası olan sosyal medya, iletişim kurma ve yaşam biçimlerini çok farklı boyutlara taşımıştır. İnsanlık tarihi boyunca en hızlı büyüyen medya türlerinden biri olan sosyal medya sürekli çeşitlenmekte ve yenilenmektedir.

Teknoloji ve iletişim alanındaki bu değişimler eğitim alanında da etkisini göstermektedir. Çağdaş eğitimin hedefi; bilgiyi üreten, bilgiyi kullanan, sürekli öğrenme alışkanlığı edinmiş ve yaratıcı nitelikte bilgi insanlarını yetiştirmektir. Gelişen bilişim teknolojilerinden okullarımızın yararlanması, bilgisayar ve internetin eğitim alanına uyarlanarak kullanılması, eğitim-öğretimin kalitesinin yükseltilmesi bakımından büyük önem taşımaktadır (Demirdaş, 2001). Genç kuşakların toplumda kabul görmeleri, bilgisayar ve internet teknolojilerini yeterli düzeyde kullanabilme becerileriyle ilişkilidir (Duman, 1998), çünkü teknoloji okur-yazarı olmayan bireylerin çağın gerisinde kalmaları kaçınılmazdır (Johson \& Johnson, 2004). Yeni nesil gençlerin teknolojiye olan yakınlık ve yatkınlıkları, eğitim sistemini güncel tutmayı ve teknolojinin sağladığı imkânlardan faydalanmayı gerekli kılmaktadır. Öğrencilerin eğitimde farklı materyalleri tercih etmeleri (Gülseçen, Gürsul, Bayrakdar, Çilengir \& Canım, 2010), sosyal paylaşım sitelerinin öğrencileri pasif tüketici olmaktan çıararak 
daha iyi motive edecek şekilde, eğitim sisteminde radikal bir değişime öncülük ederek (Ziegler, 2007), sosyal medyanın eğitim amaçlı kullanılması sonucunu ortaya koymuştur.

Her zaman her yerden erişilen ve yüksek bağlanabilirlikli (McLoughlin \& Lee, 2007), zamandan ve mekândan bağımsız olan, her ortamda sınırsız erişime ve tekrara imkân sağlayan, anında geribildirim alınabilen, birden fazla duyu organına hitap ederek öğrenmeyi hızlandıran, bireyin öğrenmesini kendi hızına ve gelişimine uygun gerçekleştirmesine olanak sağlayan, karşıllklı ve yoğun bir etkileşime izin veren (Yamamoto, Demiray \& Kesim, 2010) sosyal medya, öğrenme-öğretme sürecinin ayrılmaz bir parçası haline gelerek eğitimi sınıfın dışına taşıyarak öğrencilerin daha esnek ve özgür bir eğitim almalarına katkı sağlamaktadır. Öğrencilere kendi bilgilerini oluşturma, paylaşma ve geliştirme firsatı sunan, yapılandırmacı yaklaşımın temel felsefesine uyan bu özellikler, sosyal medyanın eğitim amaçlı kullanımını kaçınılmaz kılmıstır (Barış, 2011).

Ayrıca, Web 2.0 uygulamaları bireylere hem kişiselleştirilmiş bir öğrenme (McLoughlin \& Lee, 2007) hem de sosyal etkileşimlerin bulunduğu teknik olarak amaçlı ve planlı olmayan öğrenme yani informal öğrenme ortamlarına katılma firsatı sunabilmektedir (Mejias, 2010; Pettenati \& Ranieri, 2006; Selwyn 2007). Sosyal medya ortamlarının hem formal eğitimde hem de informal eğitimde kullanımı mümkündür (Selwyn, 2007). Öğrencilerin öğrendiklerinin yaklaşık \%80’inin informal öğrenme ile gerçekleştiği (Attwell, 2007) düşünüldüğünde sosyal paylaşım sitelerinin eğitim sistemine entegre edilmesiyle üniversite öğrencilerinin formal öğrenmelerinin yanında informal öğrenmelerinde de bu siteler etkili bir öğrenme ortamı sağlayacaktır (Öztürk, 2011). Örneğin, öğrencilerin sosyal medya platformlarında derslere yönelik konuları tartışmaları, işbirlikli öğrenme olanağını elde edebilecekleri gibi (Akkoyunlu, 1999; Grant, 2008; Jones, Blackey, Fitzgibbon \& Chew, 2010; McLoughlin \& Lee, 2007; Yuen \& Yuen, 2008), öğretmenlerle daha iyi iletişim kurma (Ajjan \& Harsthone, 2008) ve birbirlerini daha iyi tanıma olanaklarını da elde edebileceklerdir (Grant, 2008). Sosyal paylaşım siteleri, çevrim-içi işbirlikli öğrenme ortamlarında uygulama topluluklarının oluşumuna olanak sağlamakta (Pettenati \& Ranieri, 2006), böylece öğrenciler bir gruba ait olarak mesleki anlamda gelişim sağlayabilmektedirler (Yuen \& Yuen, 2008).

Sosyal ağ sitelerini her yaştaki öğrencinin kullanması ve günlük yaşantısında büyük bir yer kaplaması eğitimcilerin bu alana karşı ilgi duymasını sağlamıştır (Selwyn, 2007). Sosyal paylaşım siteleri, üniversitelerin fazla desteği olmadan kolay ve ucuz bir şekilde kullanılabilmekte, öğrenciler için eğitim süreçlerine kolaylıkla entegre edilebilmektedir (Gülbahar, Kalelioğlu \& Madran, 2010). Başka bir ifadeyle sosyal paylaşım siteleri, yüksek öğretimdeki öğrencilere, akademisyenlere ve kurumlara öğrenme ve öğretim deneyimlerini zenginleştirmek, iletişim becerilerini geliştirmek, katılımı ve sosyal bağlllı̆̆1 genişletmek, akran desteğini güçlendirmek gibi birçok fayda sağlamaktadır (Jones, Blackey, Fitzgibbon \& Chew, 2010). Böylece öğrenciler üniversiteden mezun olduklarında kendi öğrenme süreçlerine web üzerinden tekrar ulaşma ve çalışmalarını inceleme olanağı bulmakta, kendi öğrenme geçmişlerine ulaşabilmektedir (Gülbahar, Kalelioğlu \& Madran, 2010).

Sonuç olarak, yeni teknolojiler hızla geliştikçe ve yayıldıkça sosyal paylaşım sitelerinin eğitim bağlamında kullanımının önemi arttığı gibi, eğitimcileri bu gelişim sürecinin dışında tutmaktan da söz edilemez. Özellikle öğretmen eğitiminde öğretmenlerin yetiştirilmesini zenginleştirmede, öğretmen adaylarının sınıflarında bu uygulamaları etkili kullanma fırsatlarını sağlamada ve onları bu sürece hazırlamada sosyal paylaşım siteleri ayrı bir önem taşımaktadır (Albion, 2008). Sosyal paylaşım sitelerinin yüksek öğretimde akademik başarı ve öğrenme performansını artırmaya yönelik olumlu bir etkisinin olabileceği ancak bu kullanım sürecinin etkili ve verimli bir biçimde gerçekleşmesi sürecinde gerekli kültürün oluşması için desteğe ihtiyacı olabilecek öğrenciler olduğu dikkate alınmalıdır (Öztürk, 2011). İnsan yaşamına çeşitli firsatların yanında sorunlar da getiren bir internet çağında yaşamaktayız. Özellikle Türkiye'nin genç bir nüfusa sahip olduğu göz önünde bulundurulduğunda, konunun önemi daha da artmaktadır (Balcı \& Gülnar, 2009). Çünkü, gençlerde oldukça sık görülen aşırı internet kullanımı; onların psikolojik ve bedensel gelişimlerini, sosyal ilişkilerini olumsuz yönde etkileyerek, akademik başarılarını düşürmektedir (Cengizhan, 2005). Buradan hareketle, teknolojinin hızla geliştiği, yaygınlaştığı bu dönemde toplumun gelişmesinde ve yeniliklere uyum sağlamasında, ayrıca ortaya çıabilecek olumsuz sonuçların önüne geçilmesinde en büyük görev eğitimcilere düşmektedir. 


\subsection{Araştırmanın Amacı}

Ülkemiz nüfusunun yarısından fazlasının sosyal medya kullanıcı sayısı olduğu düşünüldügünde ("Digital in 2017 ...”, 2017), iletişim alanındaki bu değişimin iletişimin yoğun olarak yaşandığ1 üniversite ortamında kendini hissettirmesi kaçınılmazdır. Üniversite öğrencilerinin günlük hayatlarında önemli bir yer tutan, vakitlerinin büyük bir bölümünü ayırdıkları sosyal medyaya ilişkin tutumları büyük önem arz etmektedir. Dolayısıyla, sosyal medyanın eğitsel amaçlı kullanımına yönelik yapılan araştırmalar önem kazanmaktadır. Yukarıda verilen açıklamalar doğrultusunda, bu araştırmada, üniversite öğrencilerinin sosyal medyaya ilişkin tutumlarının çeşitli değişkenler açısından incelenmesi amaçlanmıştır. Bu amaç doğrultusunda aşağıdaki sorulara yanıt aranmıştır:

1. Üniversite öğrencilerinin sosyal medyaya ilişkin tutumları hangi düzeydedir?

2. Üniversite öğrencilerinin sosyal medyaya ilişkin tutumları arasında;

\subsection{Cinsiyet,}

2.2. Sınıf düzeyi,

2.3. İkamet edilen yer,

2.4. Sosyal medyaya bağlanılan ortam,

2.5. Sosyal medyayı kullanım süresi değişkenlerine göre anlamlı bir farklılık var mıdır?

\section{YÖNTEM}

\subsection{Araştırma Modeli}

$\mathrm{Bu}$ araştırma, tarama türünde betimsel bir çalışmadır. Betimsel çalışmalar, mevcut olayların daha önceki olay ve koşullarla ilişkilerini de dikkate alarak, durumlar arasındaki etkileşimi açıklamayı hedeflemektedir (Kaptan, 1998). Tarama modeli ise, geçmişte ya da hâlen var olan bir durumu var olduğu şekliyle betimlemeyi amaçlayan araştırma yaklaşımıdır. Araştırmaya konu olan olay, birey ya da nesne, kendi koşulları içinde ve olduğu gibi tanımlanmaya çalışılır. Araştırmaya konu olan olayı birey ya da nesneleri herhangi bir şekilde değiştirme, etkileme çabası gösterilmez. Aranan şey oradadır. Önemli olan, araştırmaya konu olan her ne ise onu uygun bir şekilde gözleyip belirleyebilmektir (Karasar, 2009). Bu araştırma kapsamında da üniversite öğrencilerinin sosyal medyaya ilişkin görüşleri, ölçek yoluyla elde edilen verilere dayanarak betimlenmeye çalışılmıştır.

\subsection{Evren ve Örneklem}

Araştırmanın evrenini, 2015-2016 öğretim yllında Dicle Üniversitesi Ziya Gökalp Eğitim Fakültesinde öğrenim gören öğrenciler oluşturmaktadır. Örneklem büyüklüğünü saptamak için Cochran'ın (1962) örneklem büyüklüğü belirleme formülü kullanılmıştır. Bu formülde \%95 güven düzeyi esas alınarak, örnekleme alınması gereken öğretmen adayı sayısı 278 olarak hesaplanmıştır. Rastgele yöntemle seçilen farklı bölüm ve sınıflarda öğrenim gören 500 öğrenci örnekleme dâhil edilmiştir. 2015-2016 bahar döneminde 500 öğretmen adayına ölçek dağıtılmış, 413 ölçek geri dönmüştür. Uygun şekilde doldurulmayan 14 ölçek değerlendirme dış1 bırakılmıştır. Dolayısıyla araştırmanın örneklemini 399 öğretmen adayı oluşturmaktadır (Tablo 1.).

Tablo 1. Araştırmaya katılan öğretmen adaylarının demografik nitelikleri

\begin{tabular}{llll}
\hline Demografik Nitelik & Gruplar & $\mathbf{N}$ & $\mathbf{\%}$ \\
\hline \multirow{2}{*}{ Yaş } & Kadın & 265 & 55.1 \\
& Erkek & 134 & 44.9 \\
\hline \multirow{3}{*}{ Sınıf düzeyi } & 1. sinıf & 205 & 51.4 \\
& 2. sinıf & 114 & 28.6 \\
& 3. sinıf & 35 & 8.8 \\
& 4. sinıf & 45 & 11.3 \\
\hline \multirow{2}{*}{ İamet edilen yer } & Ailemle & 125 & 31.3 \\
& Yalnız & 19 & 4.8 \\
& Arkadaşlarımla & 62 & 15.5 \\
Sosyal medya sitelerine bağlanılan ortam & Kablosuz internet bulunan herhangi bir yer & 193 & 48.4 \\
\hline & Mobil cihazlar & 72 & 18 \\
& Evrtta & 39.3 \\
Sosyal medyayı kullanım süresi & 1 yldan daha az & 170 & 42.6 \\
\hline Toplam & 1-2 yll & 74 & 30.6 \\
\hline
\end{tabular}


Tablo 1 incelendiğinde, öğretmen adaylarının cinsiyetlerine göre, kadın öğretmen adayları grubun \%55.1'ini ( $\mathrm{f}=265)$ temsil ederken, erkek öğretmen adayları ise grubun \%44.9'unu ( $\mathrm{f}=134)$ temsil etmektedir. Katılımcı grubun sınıf düzeyine göre dağılımına bakıldığında, \%51.4’ü (f=205) 1.sınıf, \%28.6’s1 (f=114) 2.sınıf, \%8.8’i (f=35) 3.sınıf ve \%11.3’ü ( $\mathrm{f}=45$ ) ise 4.sınıfta öğrenim görmektedir. İkamet edilen yer değişkenine göre, öğretmen adaylarının \%31.3’ü (f=125) ailesiyle ikamet ederken, \%4.8’i (f=19) yalnız, \%15.5’i (f=62) arkadaşlarıla ve \%48.4’ü ( $\mathrm{f}=193$ ) ise öğrenci yurtlarında ikamet etmektedir. Sosyal medya sitelerine bağlanılan ortam değisskenine göre, öğretmen adaylarının \%18’i (f=72) ikamet ettikleri evlerde sosyal medya sitelerine bağlanırken, \%39.3'ü (f=157) kablosuz internet bulunan herhangi bir yerde, \%42.6's1 (f=170) ise mobil cihazlarıyla sosyal medya sitelerine bağlanmaktadır. Sosyal medyayı kullanım süresine göre ise, araştırmaya katılan öğretmen adaylarının \%30.6'sı (f=122) 1 yıldan daha az bir süre sosyal medyayı kullanırken, \%18.5'i $(\mathrm{f}=74)$ 1-2 yll, \%17.5’i ( $\mathrm{f}=70)$ 3-4 y1l, \%33.3’ü ( $\mathrm{f}=133)$ ise 4 ylldan daha fazla bir süredir sosyal medyay1 kullandıkları görülmektedir (Tablo 1).

\subsection{Veri Toplama Arac1}

Araştırmada veri toplama aracı olarak, Otrar ve Argın (2015) tarafindan öğrencilerin sosyal medyaya ilişkin tutumlarını ölçmek amacıyla geliştirdikleri “Sosyal Medya Tutum Ölçeği” kullanılmıştır. Bu ölçekte; sosyal yetkinlik (6 madde), paylaşım ihtiyacı (8 madde), öğretim görevlileri ile iletişim (3 madde) ve sosyal izolasyon (6 madde) olmak üzere toplam 4 faktör ve 23 madde yer almaktadır. Otrar ve Argin (2015) tarafindan ölçeğin Cronbach alfa katsayısı .85 olarak hesaplanmıştır.

$\mathrm{Bu}$ araştırmada kullanılan veri toplama aracı ise, iki bölümden oluşmaktadır. Birinci bölümde, araştırma kapsamına alınan öğretmen adaylarının demografik özelliklerine (cinsiyet, sınıf düzeyi, ikamet edilen yer, sosyal medya sitelerine bağlanılan ortam, sosyal medyayı kullanım süresi) yer verilirken, ikinci bölümde ise öğretmen adaylarının sosyal medyaya ilişkin tutumlarını ölçmek amacıyla yukarıda bahsi geçen ölçeğin 4 boyutunda yer alan 23 maddeye yer verilmiştir.

$\mathrm{Bu}$ çalışmadan elde edilen verilere dayanarak ölçeğin güvenirliğini test etmek amaciyla diğer bir deyişle ölçeğin iç tutarlılığını anlayabilmek için, uygulanan güvenirlik hesaplaması sonucunda güvenirlik katsayısı olarak Alpha = .74 olarak bulunmuştur. Ölçeğin iç tutarlıllı̆ı için Cronbach-Alpha katsayıları alt boyutlara göre de hesaplanmış ve sonuçlar Tablo 2'de verilmiştir.

Tablo 2. Sosyal Medya Tutum Ölçeğinin Alt Boyutları ve Cronbach-Alfa Katsayıları

\begin{tabular}{lcc}
\hline Boyutlar & Boyutlarla İlgili Maddeler & Cronbach-Alpha Katsayıları \\
\hline Sosyal yetkinlik & $1-2-8-16-18-20$ & .78 \\
Paylaşım ihtiyacı & $4-5-6-12-13-15-17-21$ & .86 \\
Öğretim görevlileri ile iletişim & $9-10-19$ & .72 \\
Sosyal izolasyon & $3-7-11-14-22-23$ & .81 \\
\hline Toplam & & .74 \\
\hline
\end{tabular}

Ölçekte yer alan maddelerdeki ifadelere deneklerin katılma düzeylerini belirlemek için, "Tamamen katıllyorum”, “Katılıyorum”, “Kararsızım”, “Katılmıyorum”, “Kesinlikle katılmıyorum” şeklinde beş seçenek oluşturulmuştur. Üniversite öğrencilerinin sosyal medyaya ilişkin tutumlarını belirleyebilmek için, olumlu anlam taşıyan 17 madde sırasıyla 5, 4, 3, 2, 1; olumsuz anlam taşıyan 6 madde ise bunun tersi bir puanlamaya tabi tutulmuştur.

Denek yanıtları, boyutlar çerçevesinde, aritmetik ortalama değerlerine göre, $\bar{x} \leq 1.80$ Kesinlikle Katılmıorum; $1.81 \leq \bar{x} \leq 2.60$ Katılmıorum; $2.61 \leq \bar{x} \leq 3.40$ Kararsızım; $3.41 \leq \bar{x} \leq 4.20$ Katıliyorum ve $\bar{x} \geq 4.21$ Tamamen Katıliyorum şeklinde düzeyler oluşturulmak suretiyle seçeneklere verilen yanıtlar değerlendirilmiştir.

\subsection{Verilerin Analizi}

Verilerin analizi SPSS istatistik paket programı kullanılarak yapılmıştır. Araştırmaya katılan öğretmen adaylarının demografik özellikleri ile, boyutlar temelinde sosyal medyaya ilişkin tutumlarının betimlenmesinde yüzde ve frekans istatistikleri kullanılmıştır. Araşı̧ımanın alt amaçlanı doğrultusunda belirlenen bağımsız değişkenlere ilişkin elde edilen verilerin analiz edilmesinde kullanılacak istatistiksel yöntemleri belirlemek amacıyla normal dağılıma uygunluk analizinde Kolmogrov-Smirnov Z sınamasına başvurulmuştur. Ayrıca 
verilerin homojenlik durumunu tespit etmek için Levene sınaması kullanılmıştır. Bu sınamalar neticesinde; cinsiyet değişkeninde Independent-Samples t Test; sınıf düzeyi ve ikamet edilen yer değişkenlerinde Kruskal Wallis-H Testi; sosyal medya sitelerine bağlanılan ortam ile sosyal medyayı kullanım süreleri değişkenlerinde ise Tek Faktörlü Varyans Analizi (One-Way ANOVA) kullanılmıştır. Bu testler sonucunda anlamlı farklıllğın hangi denek grupları arasında gerçekleştiğini belirleyebilmek için Least Significant Difference (LSD) test ve Mann Whitney U Testi ile çoklu karşılaştırmalar yapıllmıştır.

\section{BULGULAR}

Öğretmen adaylarının, sosyal medyaya ilişkin tutumlarını belirlemek amacıyla, örneklem grubunun cinsiyet, sınıf düzeyi, ikamet edilen yer, sosyal medya sitelerine bağlanılan ortam ve sosyal medyayı kullanım süresi değişkenlerine ilişkin elde edilen bulgular aşağıda yorumlanmıştır.

\section{1. Öğretmen Adaylarının Boyutlar Temelinde Genel Görüşlerine Göre Bulgular ve Yorumu}

Öğretmen adaylarının boyutlar temelinde, sosyal medyaya ilişkin tutumlarının verildiği Tablo 3 incelendiğinde, en yüksek düzeyde katılım gösterdikleri boyutun sosyal medyaya ilişkin olumsuz ifadelerin yer aldığı "sosyal izolasyon" ( $\overline{\times}=3.47)$ boyutu olduğu, en düşük düzeyde katılım gösterdikleri boyutun ise "sosyal yetkinlik" ( $\bar{x}=2.36)$ boyutu olduğu görülmektedir. Diğer boyutlara ise azalan bir sırada "paylaşım ihtiyacı" $(\bar{x}=3.05)$ ve "öğretim görevlileri ile iletişim" $(\bar{x}=2.52)$ katılım gösterdikleri görülmektedir.

Tablo 3. Öğretmen adaylarının boyutlar temelinde genel görüşlerine göre betimsel istatistikler

\begin{tabular}{llccccc}
\hline & Boyutlar & $\mathbf{N}$ & $\overline{\mathrm{X}}$ & $\mathbf{S S}$ & $\mathbf{S H}$ & Yorum \\
\hline & Sosyal yetkinlik & 399 & 2.36 & 0.85 & 0.04 & Alt düzey \\
& Paylaşım ihtiyacı & 399 & 3.05 & 0.90 & 0.05 & Orta düzey \\
& Öğretim görevlileri ile iletişim & 399 & 2.52 & 1.04 & 0.05 & Alt düzey \\
& Sosyal izolasyon & 399 & 3.47 & 0.93 & 0.05 & Üst düzey \\
\hline
\end{tabular}

Ayrıca, puan ortalamaları dikkate alınarak bir değerlendirme yapıldığında; öğretmen adaylarının sosyal medyanın "sosyal yetkinlik" ile "öğretim görevlileri ile iletişim kurma” olanaklarını sağlamaya yönelik tutumları "alt düzeyde", "paylaşım ihtiyacını gidermeye" yönelik tutumları "orta düzeyde" iken, sosyal medyanın "sosyal izolasyona neden olmaya” yönelik tutumlarının ise "üst düzeyde olduğu görülmektedir. Ayrıca, öğretmen adaylarının sosyal medyaya ilişkin yukarıda verilen boyutlara genel katılımlarının ise $(\overline{\times}=2.98)$ "orta düzeyde" olduğu anlaşılmaktadır (Tablo 3).

\subsection{Cinsiyet Değişkenine Göre Bulgular ve Yorumu}

Öğretmen adaylarının, sosyal medyaya ilişkin tutumlarının cinsiyet değişkenine göre farklılık gösterip göstermediğini belirlemek için yapılan bağımsız örneklemler t-sınamasına göre, "sosyal yetkinlik" boyutunda kadın katılımciların puan ortalamas $\left(\bar{x}_{A}=2.28\right)$ ile erkek katılımciların puan ortalaması $\left(\bar{x}_{B}=2.50\right)$ arasinda erkek katılımcı grubun lehine anlamlı bir farklılık ortaya çıkmıştır $\left[\mathrm{t}_{(397)}=-2.45, \mathrm{p}<.05\right]$. Bu bulguya göre, sosyal medyanın sosyal yetkinlik kazandırmasına yönelik tutumlar ile cinsiyet arasında anlamlı bir ilişkinin olduğu söylenebilir. Erkek katılımcılar, kadın katılımcılara göre sosyal medyanın sosyal yetkinlik kazandırmasına daha yüksek düzeyde katılım göstermelerine karşın, her iki grubun sosyal medyanın sosyal yetkinlik kazandırmasına ilişkin tutumlarının "alt düzeyde" olduğu anlaşılmaktadır (Tablo 4).

Hesaplanan Eta Kare değerleri incelendiğinde, öğretmen adaylarının cinsiyetlerinin, sosyal medyanın sosyal yetkinlik kazandırmaya yönelik görüşleri üzerinde \%2'lik bir etkiye sahip olduğu belirlenmiştir. Eta Kare’nin yorumlanmasında dikkate alınan ölçütlere göre bu anlamlı etkinin küçük olduğu söylenebilir. 
Tablo 4. Boyutlar temelinde cinsiyet değişkenine göre verilerin dağılımı

\begin{tabular}{|c|c|c|c|c|c|c|c|c|}
\hline Boyutlar & Gruplar & $\mathbf{N}$ & $\bar{X}$ & SS & sd & $\mathbf{t}$ & $\mathbf{P}$ & $\begin{array}{c}\text { Eta Kare } \\
(\eta 2)\end{array}$ \\
\hline \multirow{3}{*}{ Sosyal yetkinlik } & A) Kadın & 265 & 2.28 & .83 & 397 & -2.45 & $.01 *$ & .02 \\
\hline & B) Erkek & 134 & 2.50 & .87 & & & & \\
\hline & Toplam & 399 & & & & & & \\
\hline \multirow{3}{*}{ Paylaşım ihtiyacı } & A) Kadin & 265 & 3.08 & .90 & 397 & .71 & .48 & - \\
\hline & B) Erkek & 134 & 3.01 & .89 & & & & \\
\hline & Toplam & 399 & & & & & & \\
\hline \multirow{3}{*}{$\begin{array}{l}\text { Öğretim görevlileri ile } \\
\text { iletişim }\end{array}$} & A) Kadin & 265 & 2.52 & 1.05 & 397 & -.03 & .98 & - \\
\hline & B) Erkek & 134 & 2.52 & 1.02 & & & & \\
\hline & Toplam & 399 & & & & & & \\
\hline \multirow{3}{*}{ Sosyal izolasyon } & A) Kadın & 265 & 3.52 & .94 & 397 & 1.46 & .14 & - \\
\hline & B) Erkek & 134 & 3.37 & .91 & & & & \\
\hline & Toplam & 399 & & & & & & \\
\hline
\end{tabular}

Diğer boyutlar olan paylaşım ihtiyac1 [ $\left.\mathrm{t}_{(299)}=0.71, \mathrm{p}>.05\right]$, ögretim görevlileri ile iletişim $\left[\mathrm{t}_{(299)}=-0.03, \mathrm{p}>\right.$ .05] ve sosyal izolasyon $\left[\mathrm{t}_{(299)}=1.46, \mathrm{p}>.05\right]$ boyutlarında ise öğretmen adaylarının sosyal medyaya ilişkin tutumları ile cinsiyet test puan ortalamaları arasında anlamlı bir farklılık görülmemiştir. Erkek ve kadın katılımcıların tutumları birbirine yakın olmakla birlikte, paylaşım ihtiyacı ile sosyal izolasyon boyutlarında kadın katılımcıların tutumlarının daha yüksek olduğu, öğretim görevlileri ile iletişim boyutunda ise kadın ve erkek katılımcıların tutumlarının eşit olduğu anlaşılmaktadır.

Ayrıca, her iki grubun sosyal medyanın; öğretim görevlileri ile iletişim olanağı sağlamasına yönelik tutumlarının "alt düzeyde", paylaşım ihtiyacını gidermesine yönelik tutumlarının "orta düzeyde", sosyal izolasyona neden olmasına yönelik tutumlarının ise "üst düzeyde" olduğu anlaşılmaktadır (Tablo 4).

\subsection{Sınıf Düzeyi Değişkenine Göre Bulgular ve Yorumu}

Öğrenim görülen farklı dört sınıf düzeyine göre gruplandırılmış öğretmen adaylarının, sosyal medyaya ilişkin tutumlarına yönelik Kruskal Wallis-H testi sonuçları Tablo 5’te verilmiştir.

Analiz sonuçları, araştırmaya katılan öğretmen adaylarının sosyal medyaya ilişkin tutumlarının sadece "paylaşım ihtiyacı" $\left[\chi^{2}(3)=12.281 \mathrm{p}<0.05\right]$ boyutunda farklılaştığını göstermektedir. Mann-Whitney U testi ile yapılan çoklu karşılaştırmalar bu farkın, 2.sınıfta öğrenim gören öğretmen adayları ile 4.sınıfta öğrenim gören öğretmen adaylarının tutumları arasında olduğunu göstermiştir. Bu bulgu, paylaşım ihtiyacı boyutunda öğrencilerin sosyal medyaya ilişkin tutumlarında sınıf değişkeninin etkili olduğunu göstermektedir. Grupların sıra ortalamaları dikkate alındığında, sosyal medyanın paylaşım ihtiyacını gidermeye yönelik tutumu en yüksek grubun 2.sınıfta öğrenim gören öğretmen adayları iken, en düşük tutuma sahip grubun ise 4.sınıfta öğrenim gören öğretmen adayları olduğu görülmektedir (Tablo 5).

Tablo 5. Boyutlar temelinde sınıf düzeyi değişkenine göre verilerin dağılımı

\begin{tabular}{|c|c|c|c|c|c|c|c|}
\hline Boyutlar & Gruplar & $\mathbf{N}$ & $\begin{array}{c}\text { Sira } \\
\text { Ortalamasi }\end{array}$ & Sd & $\chi^{2}$ & $\mathbf{P}$ & $\begin{array}{c}\text { Anlamlı Fark } \\
\text { (Mann } \\
\text { Whitney-U) }\end{array}$ \\
\hline \multirow{5}{*}{$\begin{array}{l}\text { Sosyal } \\
\text { yetkinlik }\end{array}$} & A) 1.sinif & 205 & 204.84 & \multirow{5}{*}{3} & \multirow{5}{*}{5.415} & \multirow{5}{*}{.14} & \multirow{5}{*}{-} \\
\hline & B) $2 . \sin 1 f$ & 114 & 205.89 & & & & \\
\hline & C) $3 . \sin 1 f$ & 35 & 200.50 & & & & \\
\hline & D) $4 . \sin 1 f$ & 45 & 162.61 & & & & \\
\hline & Toplam & 399 & & & & & \\
\hline \multirow{5}{*}{$\begin{array}{l}\text { Paylaşım } \\
\text { ihtiyacı }\end{array}$} & A) $1 . \sin 1 f$ & 205 & 194.03 & \multirow{5}{*}{3} & \multirow{5}{*}{12.281} & \multirow{5}{*}{$.01 *$} & \multirow{6}{*}{ B-D } \\
\hline & B) $2 . \sin 1 f$ & 114 & 216.24 & & & & \\
\hline & C) $3 . \sin 1 f$ & 35 & 183.47 & & & & \\
\hline & D) $4 . \sin 1 \mathrm{f}$ & 45 & 154.00 & & & & \\
\hline & Toplam & 399 & & & & & \\
\hline \multirow{5}{*}{$\begin{array}{l}\text { Öğretim } \\
\text { görevlileri ile } \\
\text { iletişim }\end{array}$} & A) $1 . \sin 1 f$ & 205 & 195.38 & \multirow{5}{*}{3} & \multirow{5}{*}{1.634} & \multirow{5}{*}{.65} & \\
\hline & B) $2 . \sin 1 f$ & 114 & 210.05 & & & & \multirow{4}{*}{-} \\
\hline & C) 3.sinif & 35 & 204.54 & & & & \\
\hline & D) $4 . \sin 1 \mathrm{f}$ & 45 & 188.49 & & & & \\
\hline & Toplam & 399 & & & & & \\
\hline \multirow{5}{*}{$\begin{array}{l}\text { Sosyal } \\
\text { izolasyon }\end{array}$} & A) 1. sinif & 205 & 196.18 & \multirow{5}{*}{3} & \multirow{5}{*}{4.195} & \multirow{5}{*}{.24} & \multirow{5}{*}{-} \\
\hline & B) $2 . \sin 1 f$ & 114 & 192.39 & & & & \\
\hline & C) 3.sinif & 35 & 206.79 & & & & \\
\hline & D) $4 . \sin 1 \mathrm{f}$ & 45 & 213.41 & & & & \\
\hline & Toplam & 399 & & & & & \\
\hline
\end{tabular}


Ancak analiz sonuçları, öğretmen adaylarının sosyal medyaya ilişkin tutumlarının sosyal yetkinlik $\left[\chi^{2}(3)\right.$ $=5.415, \mathrm{p}>0.05]$, öğretim görevlileri ile iletişim $\left[\chi^{2}(3)=1.634, \mathrm{p}>0.05\right]$ ve sosyal izolasyon $\left[\chi^{2}(3)=4.195, \mathrm{p}>\right.$ 0.05] boyutlarında sınıf düzeyi değişkenine göre anlamlı bir şekilde farklılaşmadığını göstermektedir. Ancak, söz konusu boyutlardaki katılımcı grupların sıra ortalamaları dikkate alınarak sosyal medyaya yönelik tutumlara ilişkin bir değerlendirme yapıldığında; sosyal yetkinlik ve öğretim görevlileri ile iletişim boyutlarına "2.sınıfta" öğrenim gören katılımcıların sıra ortalamalarının en yüksek, "4.sınıfta” öğrenim görenlerin sıra ortalamalarının ise en düşük olduğu görülmektedir. Buna karşıllk sosyal medyanın yol açtı̆̆1 sosyal izolasyona yönelik tutumlara ilişkin en yüksek sıra ortalamasının 4.sınıfta öğrenim görenler iken, sıra ortalaması en düşük grubun ise 2.sınıfta öğrenim görenler olduğu anlaşılmaktadır (Tablo 5).

\section{4. İkamet Edilen Yer Değişkenine Göre Bulgular ve Yorumu}

İkamet edilen farklı dört yer durumuna göre gruplandırılmış öğretmen adaylarının, sosyal medyaya ilişkin tutumlarına yönelik Kruskal Wallis-H testi sonuçları Tablo 6'da verilmiştir.

Tablo 6. Boyutlar temelinde ikamet edilen yer değişkenine göre verilerin dağılımı

\begin{tabular}{|c|c|c|c|c|c|c|c|}
\hline Boyutlar & Gruplar & $\mathbf{N}$ & $\begin{array}{c}\text { Sira } \\
\text { Ortalamas1 }\end{array}$ & Sd & $\chi^{2}$ & $\mathbf{P}$ & $\begin{array}{c}\text { Anlamlı Fark } \\
\text { (Mann } \\
\text { Whitney-U) }\end{array}$ \\
\hline \multirow{5}{*}{$\begin{array}{l}\text { Sosyal } \\
\text { yetkinlik }\end{array}$} & A) Ailemle & 125 & 203.75 & \multirow{5}{*}{3} & \multirow{5}{*}{1.557} & \multirow{5}{*}{.67} & \multirow{5}{*}{-} \\
\hline & B) Yalniz & 19 & 177.89 & & & & \\
\hline & C) Arkadaşlarımla & 62 & 193.74 & & & & \\
\hline & D) Yurtta & 193 & 207.73 & & & & \\
\hline & Toplam & 399 & & & & & \\
\hline \multirow{5}{*}{$\begin{array}{l}\text { Paylaşım } \\
\text { ihtiyacı }\end{array}$} & A) Ailemle & 125 & 198.26 & \multirow{5}{*}{3} & \multirow{5}{*}{2.547} & \multirow{5}{*}{.47} & \multirow{5}{*}{-} \\
\hline & B) Yalnız & 19 & 181.81 & & & & \\
\hline & C) Arkadaşlarımla & 62 & 191.92 & & & & \\
\hline & D) Yurtta & 193 & 207.77 & & & & \\
\hline & Toplam & 399 & & & & & \\
\hline \multirow{5}{*}{$\begin{array}{l}\text { Öğretim } \\
\text { görevlileri ile } \\
\text { iletişim }\end{array}$} & A) Ailemle & 125 & 197.71 & \multirow{5}{*}{3} & \multirow{5}{*}{3.555} & \multirow{5}{*}{.31} & \multirow{5}{*}{-} \\
\hline & B) Yalnız & 19 & 164.92 & & & & \\
\hline & C) Arkadaşlarımla & 62 & 188.47 & & & & \\
\hline & D) Yurtta & 193 & 208.64 & & & & \\
\hline & Toplam & 399 & & & & & \\
\hline \multirow{5}{*}{$\begin{array}{l}\text { Sosyal } \\
\text { izolasyon }\end{array}$} & A) Ailemle & 125 & 204.42 & \multirow{5}{*}{3} & \multirow{5}{*}{1.646} & \multirow{5}{*}{.65} & \multirow{5}{*}{-} \\
\hline & B) Yalnız & 19 & 224.42 & & & & \\
\hline & C) Arkadaşlarımla & 62 & 202.99 & & & & \\
\hline & D) Yurtta & 193 & 193.77 & & & & \\
\hline & Toplam & 399 & & & & & \\
\hline
\end{tabular}

${ }^{*} \mathrm{p}<.05,{ }^{* *} \mathrm{p}<.00$

Analiz sonuçları, ögrencilerin sosyal medyaya ilişkin tutumlarının sosyal yetkinlik $\left[\chi^{2}(3)=1.557, p>0.05\right]$, paylaşım ihtiyac1 $\left[\chi_{(3)}^{2}=2.547, \mathrm{p}>0.05\right]$, öğretim görevlileri ile iletişim $\left[\chi^{2}(3)=3.555, \mathrm{p}>0.05\right]$ ve sosyal izolasyon $\left[\chi^{2}(3)=1.646, \mathrm{p}>0.05\right]$ gibi tüm boyutlarda ikamet edilen yere göre anlamlı bir şekilde farklılaşmadığını göstermektedir. Bu bulgu, ikamet edilen yer değişkenin öğrencilerin sosyal medyaya ilişkin tutumları üzerinde etkili olmadığını göstermektedir (Tablo 6).

Ancak, grupların sıra ortalamaları dikkate alınarak bir değerlendirme yapıldığında; sosyal yetkinlik, paylaşım ihtiyacı ve öğretim görevlileri ile iletişim boyutlarında "yurtta" ikamet eden katılımcıların tutumlarına ilişkin sıra ortalamalarının en yüksek, "yalnız" ikamet edenlerin sıra ortalamalarının ise en düşük olduğu görülmektedir. Buna karşılık, sosyal izolasyon boyutunda "yalnız" ikamet eden katılımcıların sıra ortalamalarının en yüksek, yurtta ikamet edenlerin sıra ortalamalarının ise en düşük olduğu görülmektedir (Tablo 6).

\subsection{Sosyal Medya Sitelerine Bağlanılan Ortam Değişkenine Göre Bulgular ve Yorumu}

Araştırmaya katılan üniversite öğrencilerinin sosyal medyaya ilişkin tutumlarının sosyal medya sitelerine bağlanılan ortam değişkenine göre anlamlı bir farklılık gösterip göstermediğini belirlemek amacıyla ilişkisiz örneklemler için tek yönlü varyans analizi (ANOVA) yapılmıştır.

Analiz sonuçları; sosyal yetkinlik $\left[\mathrm{F}_{(2-408)}=0.63, \mathrm{p}>0.05\right]$, paylaşım ihtiyac1 $\left[\mathrm{F}_{(2-408)}=1.31, \mathrm{p}>0.05\right]$, öğretim görevlileri ile iletişim $\left[\left[\mathrm{F}_{(2-408)}=1.63, \mathrm{p}>0.05\right]\right.$ ve sosyal izolasyon $\left[\mathrm{F}_{(2-408)}=2.62, \mathrm{p}>0.05\right]$ boyutlarında öğrencilerin sosyal medyaya yönelik tutumları arasında sosyal medya sitelerine bağlanılan ortam bakımından istatistiksel olarak anlamlı bir fark olmadığını göstermektedir (Tablo 7). 
Ancak, sosyal medyaya yönelik tutumlar ile sosyal medya sitelerine bağlanılan ortam değişkeni arasında anlamlı farklılık görülmese de sosyal yetkinlik, paylaşım ihtiyacı ve öğretim görevlileri iletişim boyutlarında "kablosuz internet bulunan herhangi bir yerde" sosyal medya sitelerine bağlanan grubun sosyal medyaya yönelik tutumlarının, "ev" ve "mobil cihazlar" ortamlarında bağlanan gruplara nazaran daha olumlu olduğu görülmektedir. Ayrıca, “ev" ortamında sosyal medya sitelerine bağlanan grubun, sosyal medyanın sosyal izolasyona neden olduğuna yönelik katılımlarının ise, diğer gruplara nazaran daha yüksek olduğu görülmektedir (Tablo 7).

Tablo 7. Boyutlar temelinde sosyal medya sitelerine bağlanılan ortam değişkenine göre verilerin dağılımı

\begin{tabular}{|c|c|c|c|c|c|c|c|c|c|c|}
\hline Boyutlar & Gruplar & $\mathbf{N}$ & $\bar{X}$ & $\begin{array}{c}\text { Varyansın } \\
\text { Kaynağı }\end{array}$ & $\begin{array}{l}\text { Kareler } \\
\text { Toplamı }\end{array}$ & Sd & $\begin{array}{c}\text { Kareler } \\
\text { Ortalaması }\end{array}$ & $\mathbf{F}$ & $\mathrm{p}$ & $\begin{array}{c}\text { Anlamli } \\
\text { fark } \\
\text { (LSD) }\end{array}$ \\
\hline \multirow{4}{*}{$\begin{array}{l}\text { Sosyal } \\
\text { yetkinlik }\end{array}$} & A) $\mathrm{Ev}$ & 72 & 2.28 & \multirow{2}{*}{$\begin{array}{l}\text { Gruplar } \\
\text { aras1 }\end{array}$} & \multirow{2}{*}{.905} & \multirow{2}{*}{2} & \multirow{2}{*}{.453} & \multirow{4}{*}{.63} & \multirow{4}{*}{.53} & \multirow{4}{*}{ - } \\
\hline & B) Herhangi bir yer & 157 & 2.41 & & & & & & & \\
\hline & C) Mobil cihazlar & 170 & 2.34 & \multirow[t]{2}{*}{ Gruplar içi } & 284.344 & 408 & \multirow[t]{2}{*}{.718} & & & \\
\hline & Toplam & 399 & 2.36 & & 285.249 & 410 & & & & \\
\hline \multirow{4}{*}{$\begin{array}{l}\text { Paylaşım } \\
\text { ihtiyacı }\end{array}$} & A) $\mathrm{Ev}$ & 72 & 2.91 & \multirow{2}{*}{$\begin{array}{l}\text { Gruplar } \\
\text { aras1 }\end{array}$} & \multirow{2}{*}{2.122} & \multirow{2}{*}{2} & \multirow{2}{*}{1.061} & \multirow{4}{*}{1.31} & \multirow{4}{*}{.27} & \multirow{4}{*}{-} \\
\hline & B) Herhangi bir yer & 157 & 3.12 & & & & & & & \\
\hline & C) Mobil cihazlar & 170 & 3.05 & \multirow[t]{2}{*}{ Gruplar içi } & 320.273 & 408 & .809 & & & \\
\hline & Toplam & 399 & 3.05 & & 322.395 & 410 & & & & \\
\hline \multirow{4}{*}{$\begin{array}{l}\text { Öğretim } \\
\text { görevlileri ile } \\
\text { iletişim }\end{array}$} & A) $\mathrm{Ev}$ & 72 & 2.35 & \multirow{2}{*}{$\begin{array}{l}\text { Gruplar } \\
\text { aras1 }\end{array}$} & \multirow{2}{*}{3.528} & \multirow{2}{*}{2} & \multirow{2}{*}{1.764} & \multirow{4}{*}{1.63} & \multirow{4}{*}{.20} & \multirow{4}{*}{ - } \\
\hline & B) Herhangi bir yer & 157 & 2.60 & & & & & & & \\
\hline & C) Mobil cihazlar & 170 & 2.51 & \multirow[t]{2}{*}{ Gruplar içi } & 427.345 & 408 & 1.079 & & & \\
\hline & Toplam & 399 & 2.52 & & 430.873 & 410 & & & & \\
\hline \multirow{4}{*}{$\begin{array}{l}\text { Sosyal } \\
\text { izolasyon }\end{array}$} & A) $\mathrm{Ev}$ & 72 & 3.62 & \multirow{2}{*}{$\begin{array}{l}\text { Gruplar } \\
\text { aras1 }\end{array}$} & \multirow{2}{*}{4.532} & \multirow{2}{*}{2} & \multirow{2}{*}{2.266} & \multirow{4}{*}{2.62} & \multirow{4}{*}{.07} & \\
\hline & B) Herhangi bir yer & 157 & 3.34 & & & & & & & \\
\hline & C) Mobil cihazlar & 170 & 3.52 & Gruplar içi & 342.306 & 408 & .864 & & & \\
\hline & Toplam & 399 & 3.47 & & 346.837 & 410 & & & & \\
\hline
\end{tabular}

${ }^{*} \mathrm{p}<.05,{ }^{* *} \mathrm{p}<.00$

Sosyal medyaya ilişkin söz konusu boyutlarda tüm katılımcı grupların tutumları birbirine yakın olmakla birlikte, katılımcıların sosyal medyanın sosyal yetkinlik kazandırmasına ve öğretim görevlileri ile iletişim olanağ1 sağlamasına yönelik tutumlarının "alt düzeyde”, paylaşım ihtiyacını gidermesine yönelik tutumlanının “orta düzeyde", sosyal izolasyona yol açmasına yönelik tutumlarının ise, "üst düzeyde” olduğu görülmektedir (Tablo 7).

\subsection{Sosyal Medyayı Kullanım Süresi Değişkenine Göre Bulgular ve Yorumu}

Öğretmen adaylarının sosyal medyaya ilişkin tutumlarının sosyal medya sitelerini kullanım süresi değişkenine göre anlamlı bir farklılık gösterip göstermediğini belirlemek amacıyla ilişkisiz örneklemler için tek yönlü varyans analizi (ANOVA) yapılmıştır.

Analiz sonuçlar1; sosyal yetkinlik $\left[\mathrm{F}_{(3-395)}=4.00, \mathrm{p}<0.05\right]$ ve paylaşım ihtiyac1 $\left[\mathrm{F}_{(3-395)}=2.90, \mathrm{p}<0.05\right]$ boyutlarında öğretmen adaylarının tutumları arasında sosyal medyayı kullanım süresi bakımından istatistiksel olarak anlamlı bir fark olduğunu göstermektedir. Başka bir deyişle öğretmen adaylarının, sosyal medyanın sosyal etkinlik kazandırma ve paylaşım ihtiyacını gidermeye yönelik tutumları, sosyal medyayı kullanım sürelerine bağlı olarak anlamlı bir şekilde farklılaşmaktadır. Birimler arası farkların hangi gruplar arasında olduğunu bulmak amaciyla yapılan LSD testi sonucunda anlamlı farkın her iki boyutta da, "3-4 y1l” ve "4 yıldan fazla" bir süredir sosyal medya sitelerini kullanan gruplardaki katılımcılar ile "1 y1ldan az" bir süredir sosyal medya sitelerini kullanan gruptaki katılımcılar arasında olduğu görülmüştür $(\mathrm{p}=.03, \mathrm{p}=.02)$. Buna göre, 3-4 yıl ve 4 yıldan fazla sürelerde sosyal medya sitelerini kullanan katılımcıların 1 yıldan az sürede sosyal medya sitelerini kullanan katılımcılara göre, sosyal medyanın hem sosyal yetkinlik kazandırmaya hem de paylaşım ihtiyacını karşılamaya ilişkin tutumlarının daha yüksek olduğu görülmektedir. Buna karşılık, tüm katılımcı grupların sosyal medyanın sosyal yetkinlik kazandırmasına yönelik tutumlarının “alt düzeyde”, paylaşım ihtiyacını gidermesine yönelik tutumlarının ise "orta düzeyde” olduğu anlaşılmaktadır (Tablo 8). 
Hesaplanan Eta Kare değerleri incelendiğinde, öğretmen adaylarının sosyal medyayı kullanım sürelerinin, sosyal medyanın sosyal yetkinlik kazandırmaya yönelik görüşleri üzerinde \%3’lük, paylaşım ihtiyacını gidermeye yönelik görüşleri üzerinde ise \%2'lik bir etkiye sahip olduğu belirlenmiştir. Eta Kare’nin yorumlanmasında dikkate alınan ölçütlere göre bu anlamlı etkilerin küçük olduğu söylenebilir.

Tablo 8. Boyutlar temelinde sosyal medyayı kullanım süresi değişkenine göre verilerin dağılımı

\begin{tabular}{|c|c|c|c|c|c|c|c|c|c|c|c|}
\hline Boyutlar & Gruplar & $\mathbf{N}$ & $\mathrm{X}$ & $\begin{array}{c}\text { Varyansın } \\
\text { Kaynağ1 }\end{array}$ & $\begin{array}{c}\text { Kareler } \\
\text { Toplamı }\end{array}$ & Sd & $\begin{array}{c}\text { Kareler } \\
\text { Ortalamas1 }\end{array}$ & $\mathbf{F}$ & p & $\begin{array}{c}\text { Anlamli } \\
\text { fark } \\
\text { (LSD) }\end{array}$ & $\begin{array}{c}\text { Eta } \\
\text { Kare } \\
(\eta 2) \\
\end{array}$ \\
\hline \multirow{5}{*}{$\begin{array}{l}\text { Sosyal } \\
\text { yetkinlik }\end{array}$} & A) 1 yıldan az & 122 & 2.15 & Gruplar & 8420 & 3 & 2807 & \multirow{5}{*}{4.00} & \multirow{5}{*}{$.01 *$} & \multirow{5}{*}{$\begin{array}{l}\text { C-A } \\
\text { D-A }\end{array}$} & \multirow{5}{*}{.03} \\
\hline & B) 1-2 yil & 74 & 2.35 & aras1 & 0.120 & & 2.001 & & & & \\
\hline & & 70 & 2.45 & \multirow{3}{*}{ Gruplar içi } & \multirow{2}{*}{276.829} & \multirow{2}{*}{395} & \multirow{2}{*}{.701} & & & & \\
\hline & D) 4 yıldan fazla & 133 & 2.50 & & & & & & & & \\
\hline & Toplam & 399 & 2.36 & & 285.249 & 398 & & & & & \\
\hline \multirow{5}{*}{$\begin{array}{l}\text { Paylaşım } \\
\text { ihtiyacı }\end{array}$} & A) 1 yildan az & 122 & 2.89 & \multirow{2}{*}{$\begin{array}{l}\text { Gruplar } \\
\text { aras1 }\end{array}$} & \multirow{2}{*}{6.954} & \multirow{2}{*}{3} & \multirow{2}{*}{2.318} & \multirow{5}{*}{2.90} & \multirow{5}{*}{$.03^{*}$} & \multirow{5}{*}{$\begin{array}{l}\text { C-A } \\
\text { D-A }\end{array}$} & \multirow{5}{*}{.02} \\
\hline & B) $1-2 \mathrm{y} 1 \mathrm{l}$ & 74 & 3.00 & & & & & & & & \\
\hline & C) 3-4 y1l & 70 & 3.18 & \multirow{3}{*}{ Gruplar içi } & \multirow{2}{*}{315.441} & \multirow{2}{*}{395} & \multirow{2}{*}{.799} & & & & \\
\hline & D) 4 yıldan fazla & 133 & 3.22 & & & & & & & & \\
\hline & Toplam & 399 & 3.05 & & 322.395 & 398 & & & & & \\
\hline \multirow{5}{*}{$\begin{array}{l}\text { Öğretim } \\
\text { görevlileri ile } \\
\text { iletişim }\end{array}$} & A) 1 yıldan az & 122 & 2.40 & \multirow{2}{*}{$\begin{array}{l}\text { Gruplar } \\
\text { aras1 }\end{array}$} & \multirow{2}{*}{5.502} & \multirow{2}{*}{3} & \multirow{2}{*}{1.834} & \multirow{5}{*}{1.70} & \multirow{5}{*}{.17} & \multirow{5}{*}{-} & \multirow{5}{*}{-} \\
\hline & B) $1-2 \mathrm{y} 1 \mathrm{l}$ & 74 & 2.41 & & & & & & & & \\
\hline & C) 3-4 y1l & 70 & 2.58 & \multirow{2}{*}{ Gruplar içi } & \multirow{2}{*}{425.371} & 205 & 1077 & & & & \\
\hline & D) 4 yıldan fazla & 133 & 2.66 & & & גנד & 1.071 & & & & \\
\hline & Toplam & 399 & 2.52 & & 430.873 & 398 & & & & & \\
\hline & A) 1 yildan az & 122 & 3.60 & Gruplar & 5375 & 3 & 1702 & & & & \\
\hline & B) $1-2$ y1l & 74 & 3.55 & aras1 & J.J & $J$ & 1.178 & & & & \\
\hline $\begin{array}{l}\text { Sosyal } \\
\text { izolasvon }\end{array}$ & C) 3-4 y1l & 70 & 3.42 & Grunlar ici & $34146 ?$ & 305 & 86 & 2.70 & .10 & - & - \\
\hline & D) 4 yıldan fazla & 133 & 3.29 & Hupial çऽ & 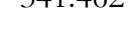 & גת & (1007 & & & & \\
\hline & Toplam & 399 & 3.47 & & 346.837 & 398 & & & & & \\
\hline
\end{tabular}

Diğer boyutlar olan, öğretim görevlileri ile iletişim $\left[\mathrm{F}_{(3-395)}=1.70, \mathrm{p}>0.05\right]$ ve sosyal izolasyon $\left[\mathrm{F}_{(3-395)}=\right.$ 2.07, $\mathrm{p}>0.05$ ] boyutlarında öğretmen adaylarının sosyal medyaya ilişkin tutumları arasında sosyal medya sitelerini kullanma süresi bakımından istatistiksel olarak anlamlı bir fark olmadığ görülmektedir. Ancak, test puan ortalamaları dikkate alınarak bir değerlendirme yapıldığında; sosyal medyanın öğretim görevlileri ile iletişim olanağı sağlaması bakımından 4 yıldan fazla süredir sosyal medya sitelerini kullanan katılımcı grubun tutumunun "orta düzeyde", diğer katılımcı gruplanın tutumlarının ise "düşük düzeyde” olduğu görülmektedir. Buna karşılık, sosyal medyanın sosyal izolasyona yol açması bakımından 4 yıldan fazla süredir sosyal medya sitelerini kullanan katılımcı grubun tutumunun "orta düzeyde" diğer katılımc1 grupların tutumlarının ise "yüksek düzeyde” olduğu anlaşılmaktadır (Tablo 8).

\section{TARTIŞMA ve SONUÇ}

Toplumsal yaşamımızda büyük değişiklikler meydana getiren internet ve sosyal medya üniversite öğrencileri tarafından yaygın olarak kullanılmaktadır. Yeni gelişmelerin eğitim sistemine entegre edilmesi ve bu değişimlerden azami derecede yarar sağlanması büyük önem taşımaktadır. Eğitimcilerin de bu yöndeki gelişmeleri takip etmeleri ve ortaya çıkan değişimleri eğitim sürecinde kullanmaları beklenilmektedir. Bu çalışma kapsamında da; cinsiyet, sınıf düzeyi, ikamet edilen yer, sosyal medyaya bağlanılan ortam ve sosyal medyayı kullanım süresi değişkenlerinin üniversite öğrencilerinin sosyal medyaya ilişkin tutumlarına olan etkisi incelenmeye çalışılmıştır.

Öğretmen adaylarının sosyal medyaya ilişkin genel görüşlerinden elde edilen sonuçlar, öğretmen adaylarının sosyal medyanın sosyal izolasyona neden olduğuna yönelik tutumları en yüksek düzeyde iken, buna karşılık sosyal medyanın sosyal yetkinlik kazandırdığına yönelik tutumlarının ise en düşük düzeyde olduğunu göstermiştir. Yani, sosyal medyanın sosyal yetkinlik kazandırmadığını düşündükleri gibi, sosyal izolasyona neden olduğunu da düşündükleri anlaşılmıştır. Alan yazında sosyal medyaya ilişkin çalışmalarda da benzer 
sonuçların elde edildiği görülmektedir. Turnalar Kurtaran (2008)'1n lise öğrencileri üzerinde internet bağımlılığını yordayan değişkenleri incelemek amacıyla yaptığı araştırmada da internet bağımlılık düzeyi ile yalnızlık değişkenine ilişkin bulguları incelemiş ve yalnızlığın internet bağımlılığını pozitif yönde anlamlı bir şekilde yordadığı sonucuna ulaşmıştır. Dolayısıyla, öğrencilerin internet ve sosyal medya ağlarında çok fazla zaman geçirmelerinin sosyal hayattan uzaklaşmalarına ve yalnızlaşmalarına neden olduğu söyleyebilir. Buna karşılık, Ajjan ve Harsthone (2008) sosyal ağları eğitsel bağlamda kullanmak için uygun bir araç olarak görmekte ve sosyal ağların öğrenci öğrenmelerini arttırdığını, okul-öğrenci ve öğrenci-öğrenci arasında etkileşim sağladığını, öğrencilerin derslere ilişkin memnuniyetlerini arttırdığını, öğrencilerin yazma becerilerini geliştirdiğini ve derslere uyumu kolay araçlar olduğunu ortaya koymuşlardır. Selwyn (2007) de, sosyal ağların özellikle öğrencilerin akademik çalışmalarında, öğretici personele ve akademik sohbetlerdeki ilişkilerde içine düştükleri rol karmaşasının üstesinden gelmelerine yardımcı olduğunu ileri sürmüştür.

$\mathrm{Bu}$ araştırma sonucunda, üniversite öğrencilerinin sosyal medyaya ilişkin tutumlarının cinsiyetleri açısından çok fazla farklılık göstermediği ancak, sosyal medyanın sosyal yetkinlik kazandırması bakımından erkek öğrencilerin kadın öğrencilere nazaran anlamlı bir şekilde daha olumlu bir tutum sergiledikleri görülmüştür. Bu sonucu destekler nitelikte Argın (2013)'ın çalışmasında da öğrencilerin sosyal yetkinlik ve sosyal izolasyon alt boyutlanından aldıkları puanların öğrencilerin cinsiyetine göre anlamlı farklılık gösterdiği belirlenmiş ve her iki farklılığın da erkek öğrencilerin lehine gerçekleştĭgi tespit edilmiştir. Bu sonuç erkek öğrencilerin sosyal yetkinliklerinin daha yüksek olduğu ve sosyal medya siteleri ile sosyal hayattan daha fazla izole oldukları şeklinde yorumlanabilir. Bu durumun toplumumuzda erkeklerin daha serbest hareket edebilmelerinden, erkeklerin evlerinde internet olmasa bile internet salonlarına rahatlıkla giderek uzun süre bu salonlarda vakit geçirebilmelerinden, çeşitli amaçlarla interneti ve sosyal medya ağlarını kullanabilmelerinden ve ayrıca sosyal ağlarda daha rahat davranış sergileyebilmelerinden kaynaklandığı düşünülmektedir. Oysa kızların teknolojiye karşı olumlu tutumlarına ait bulguların başka çalışmalarda ortaya konulduğu görülmektedir. Örneğin, Çil (2008), öğretmen adaylarının teknolojinin eğitim-öğretim faaliyetlerindeki rolüne ait görüşlerini incelemek amacıyla yaptığı çalışmada, öğretmen adaylarının genel olarak olumlu görüşlere sahip olduğunu belirlemiştir. Aynı çalışmada, kız öğretmen adaylarının görüşlerinin erkek öğretmen adaylarına göre daha olumlu olduğu sonucunu da ulaşılmıştır. Diğer yandan, internet bağımlılı̆̆ ile ilgili araştırmalarda ise, cinsiyet değişkeni açısından farklı sonuçlara rastlanıldığı görülmüştür: Morahan-Martin ve Schumacker (2000) ile Chou, Condron ve Belland (2005)'nin araştırmalarında, erkeklerin kızlara göre daha çok internet bağımlısı olduğu; Young'ı (1998) araştırmasında kızların erkeklere göre daha çok internet bağımlısı olduğu; Brenner (1997); Soule, Shall ve Kleen (2003); Lee ve diğerleri (2007) ile Ferraro, Caci, D’amico ve Blasi'nin (2007) araştırmalarında ise kızlarla erkekler arasında internet bağımlılığı açısından fark olmadığı ortaya çıkmıştır.

Öğrenim görülen farklı dört sınıf düzeyine göre gruplandırılmış öğretmen adaylarının, sosyal medyaya ilişkin tutumlarının sadece "paylaşım ihtiyacı" boyutunda anlamlı bir farklılık gösterdiği ve bu farkın 2.sınıfta öğrenim gören öğretmen adayları ile 4.sınıfta öğrenim gören öğretmen adaylarının tutumları arasında olduğu görülmüştür. Bu bulgu, paylaşım ihtiyacı boyutunda öğrencilerin sosyal medyaya ilişkin tutumlarında sınıf değişkeninin etkili olduğunu göstermektedir. Sosyal medyanın paylaşım ihtiyacını gidermeye yönelik tutumu en yüksek grubun 2.sınıfta öğrenim gören öğretmen adayları iken, en düşük tutuma sahip grubun ise 4.sınıfta öğrenim gören öğretmen adayları olduğu sonucuna ulaşılmıştır. Bu durum üst sınıfların kendi kendilerine yetebilmesi, alt sınıfların ise birbirlerine danışma ihitiyacının daha fazla olması ile ilgili olabilir. Sınıf düzeyi değişkenine göre, paylaşım ihtiyacı boyutunda 2. sınıf öğrencilerinin tutumlarının yüksek olması, yeni gelen neslin sosyal medya üzerinden mesaj verme, kendi varllğını hissettirme gibi konularda daha etkili olduğunu göstermesi bakımından önem taşımaktadır.

Öğretmen adaylarının, sosyal medyaya ilişkin tutumlarının sosyal yetkinlik, paylaşım ihtiyacı, öğretim görevlileri ile iletişim ve sosyal izolasyon boyutlannda ikamet edilen yere göre anlamlı bir şekilde farklılaşmadığı görülmüsstür. Bu bulgu, ikamet edilen yer değişkenin öğrencilerin sosyal medyaya ilişkin tutumları üzerinde etkili olmadığını göstermiştir. Ancak, grupların sıra ortalamaları dikkate alınarak bir değerlendirme yapıldığında; sosyal yetkinlik, paylaşım ihtiyacı ve öğretim görevlileri ile iletişim boyutlarında 
"yurtta" ikamet eden katılımcıların tutumlarına ilişkin sıra ortalamalarının en yüksek, "yalnız" ikamet edenlerin sıra ortalamalarının ise en düşük olduğu görülmüştür. Buna karşılık, sosyal izolasyon boyutunda "yalnız" ikamet eden katılımcıların sıra ortalamalarının en yüksek, yurtta ikamet edenlerin sıra ortalamalarının ise en düşük olduğu görülmektedir. İkamet edilen yer değişkeni ile ilgili yalnız kalan öğrencilerin sosyal açıdan yaşadıkları eksiklikleri sosyal medya aracilığı ile giderdikleri, yurtta kalan öğrencilerin ise paylaşım ve öğretim görevleri ile iletişim açılarından sosyal medyayı diğer öğrencilerden daha fazla kullandıkları şeklinde yorumlanabilir. Kandell (1998), üniversite öğrencilerinin diğer öğrencilerden daha fazla internet bağımlıs1 olduğunu belirtmektedir. Bunun nedeni olarak; üniversite öğrencilerinin evlerinden uzak yurtlarda yaşamakta olduğu, ailelerinin yönlendirmeleri olmadan boş vakitlerini yanlış değerlendirebilmeleri, bu dönemdeki öğrencilerin kişilerarası ilişkilere yönelmeleri ve eğitim sisteminin öğrencileri internet kullanımına yönlendirmesi gösterilmektedir.

Araştırmaya katılan üniversite öğrencilerinin sosyal medyaya ilişkin tutumlarında sosyal medya sitelerine bağlanılan ortam değişkenine göre anlamlı bir farklılık görülmemiştir. Ancak, sosyal yetkinlik, paylaşım ihtiyacı ve öğretim görevlileri iletişim boyutlarında "kablosuz internet bulunan herhangi bir yerde" sosyal medya sitelerine bağlanan grubun sosyal medyaya yönelik tutumlarının, "ev" ve "mobil cihazlar" ortamlarında bağlanan gruplara nazaran daha olumlu olduğu sonuçlarına ulaşılmıştır. Ayrıca, "ev" ortamında sosyal medya sitelerine bağlanan grubun, sosyal medyanın sosyal izolasyona neden olduğuna yönelik kattlımlarının ise, diğer gruplara nazaran daha yüksek olduğu görülmüştür. Akbulut ve Y1lmazel (2012)'in ergen yaş grubunda internet bağımlılı̆̆ düzeyini belirlemek amacıyla yaptığı çalışmada da okulda internet kullandığını belirten ergenlerin bağımlılık puanlarının internet kafe ve evde internet kullananlara göre daha fazla olduğunu ancak internetin kullanıldığı yer bakımından gruplar arasındaki farklılığın anlamlı olmadığını belirtmesi araştırmanın sonucunu desteklemektedir. Tektaş (2014)'ın çalışmasında internete bağlanmak için kullanılan cihaz \%42,1 ile cep telefonları olmuştur. Bu durum günümüz gençliğinin çoğunun kendilerine ait kişisel mobil cihazlara sahip olmasıyla internete kolayca erişim sağlayabilmesinden kaynaklanmaktadır. Günümüzde gençler mobil cihazlarıyla her an her yerden internete bağlanabilmektedirler.

Sosyal medyayı kullanım süresi değişkenine ilişkin elde edilen sonuçlar, üniversite öğrencilerinin sosyal medayanın yetkinlik kazandırmaya ve paylaşım ihtiyacını gidermeye yönelik tutumlarının anlamlı bir şekilde farklılaştığını ortaya koymuştur. Bu sonuca göre, 3-4 yıl ve 4 yıldan fazla sürelerde sosyal medya sitelerini kullanan katılımcıların 1 yıldan az sürede kullanan katılımcılara göre, sosyal medyanın hem sosyal yetkinlik kazandırmaya hem de paylaşım ihtiyacını karşılamaya ilişkin tutumlarının daha yüksek olduğu görülmüştür. Dolayısıyla, 3 yıl ve daha fazla süre sosyal medya ağlarını kullanan öğrencilerin sosyal medyaya ilişkin tutumlarının daha olumlu olduğu söylenebilir. Alan yazında sosyal medyanın kullanım süresi değişkenini konu edinen araştırmalarda da bu sonucu destekler bulguların elde edildiği görülmektedir. Öztürk (2011)'ün çalışmasında üniversite öğrencilerinin sosyal paylaşım sitelerini ortalama 4 yıldan uzun bir süre ve çoğunluğu her gün olmak üzere yoğun bir şekilde kullandıklarını göstermektedir. Tektaş (2014)'ın çalışmasında ise, öğrencilerin, sosyal ağları 5 yıldan fazla kullanıyor olmalarının oranının \%53,8 olması, yine onların internet ve bilgisayarla erken tanışmaları ve yaşıtları ile paylaşımda bulunmak için kendilerini sosyal ağları kullanmak zorunda hissediyor olmaları ile açıklanabilir. Karaman, Yıldırım ve Kaban (2008) tarafından yapılan araştırmaya göre, öğrencilerin \%11,86 oranıyla sosyal paylaşım sitelerini derslere çevirim-içi destek olarak kullandıkları saptanmıştır. Ayrıca Tekinarslan ve Gürer (2011) tarafından yapılan araştırmaya göre, üniversite öğrencilerinin sosyal paylaşım sitelerini kullandıktan sonra düşüncelerini ifade etme becerilerinin $(\% 57,6)$ arttığ1 yönünde olumlu görüş belirttikleri saptanmıştır. Baran'ın (2010) yaptı̆̆1 deneysel çalışmaya katılan öğrencilerin tümü üniversitede eğitim veren öğretim elemanlarının derslerini desteklemek için sosyal paylaşım sitelerini kullanmaları gerektiğini belirtmişlerdir. Bununla birlikte deneysel işlemlere katılan öğrencilerin \%72'si dersin sosyal paylaşım sitelerine dayalı olarak yürütülmesinin öğretime katkı sağlayıp sağlamayacağı konusunda kararsızdırlar. Bununla birlikte öğrencilerin \%59’u deneysel olarak katıldıkları derste olduğu gibi her derse ait bir sosyal paylaşım sitesinden yararlanmak istediklerini belirtmektedirler. Öğrencilerin \%65,7’si sosyal paylaşım sitelerini kullanmanın öğrenmeye güdülenmelerini sağlamaya yardımc1 olduğu, \%62,5’i çalışmalarıyla ilgili 
öğretmen geribildirimlerini heyecanla beklediklerini söylemektedirler. Öztürk (2011)’ün çalışmasında araştırmaya katılanların büyük çoğunluğu sosyal paylaşım sitelerine haftada en az bir kez girmektedir. Çoğunluğunun ise \%50,8 oranılla sosyal paylaşım sitelerini her gün kullandıkları görülmektedir. Bu sonuçlardan hareketle, üniversite öğrencilerinin sosyal paylaşım sitelerini sıklıkla kullandıkları söylenebilir. Ayrıca, Erzurum ve Tiryakioğlu (2011) tarafindan öğretim görevlileri ve öğretim elemanları üzerinde yaptıkları araştırma sonucuna göre katılımcıların \% 56’sının her gün, \%28'inin haftada birkaç kez, \%12'sinin ayda birkaç kez ve \%4'ünün ise yılda birkaç kez sosyal paylaşım sitelerinden olan Facebook hesaplarına giriş yaptıklarını belirtmişlerdir. Horzum (2010) tarafından yapılan araştırma sonucuna göre, öğretmenlerin \%33,87 oranıyla web 2.0 araçlarını haftada bir veya birkaç gün kullandıkları saptanmıştır. Taylor, Parker, Lenhart ve Patten (2011) tarafindan 1055 üniversite rektörü ile görüşerek yaptıkları araştırmanın sonucuna göre, rektörlerin \%32'si sosyal paylaşım sitelerini haftada birden daha sık şekilde kullanmaktadır. Bu bulgular sosyal medyanın eğitim sürecinde etkili olarak kullanılmasının önemini göstermektedir. Albion (2008), yeni teknolojiler hızla geliştikçe ve yayıldıkça bu araçların eğitim bağlamında kullanımının önemini vurguladığı gibi, eğitimcileri bu gelişim sürecinin dışında bırakmanın da söz konusu olmadığını ve özellikle öğretmen eğitiminde öğretmenlerin yetiştirilmesini zenginleştirme ve öğretmen adaylarını sınıflarında bu uygulamaları etkili kullanma firsatlarını sağlama ve onları bu sürece hazırlamada ayrı önem taşıdığını ifade etmiştir.

Elde edilen bu sonuçlardan yola çıkarak aşağıdaki önerilere yer verilebilir:

1. Ülkemizde 2004 yllında gündeme gelen “Medya Okuryazarlığı Projesi” RTÜK ve MEB işbirliği ile 2006 yllında hayata geçirilmiş ve 2007-2008 eğitim-öğretim yllından itibaren ise Medya Okuryazarllğı dersi tüm Türkiye'deki ilköğretim okullarında 6,7 ve 8 . sınıflarda seçmeli ders olarak okutulmaya başlatılmıştır. Günümüzde zamanının çoğunu internette geçiren ve her gördüğüne inanan gençler için Medya Okuryazarlığı eğitimi büyük önem taşımaktadır. Medya Okuryazarlığı dersinin okulöncesi eğitimden başlayarak yaşam boyu öğrenme sürecinde yer alması ve zorunlu ders olması önerilebilir. Böylece, gençlerin sosyal medyada her gördüklerine inanmamaları gerektiğini, bu bilgilerin hepsinin gerçeğini yansıtmadığını küçük yaşlardan itibaren öğrenmeleri sağlanabileceği gibi, Medya Okuryazarlı̆̆1 dersiyle eleştiren ve sorgulayan bir bakış açısı kazanmaları da sağlanabilir.

2. Eğitimciler, öğrencilerin sıklıkla kullandıkları ve hayatlarının ayrılmaz bir parçası olan sosyal medya ağlarının eğitimde etkili kullanımı sağlayarak, bu durumu eğitim açısından bir firsata dönüştürebilirler. Öğretim görevlilerinin sosyal medya ağlarını, bir eğitim aracı olarak eğitim-öğretim sürecinde daha etkin bir şekilde kullanmalarına yönelik olanaklar geliştirilebilir.

3. Öğrencilerin hayatlarının olumsuz etkilenmemesi ve sosyal hayattan kopmamaları için bilgisayar ve internet başında geçirdikleri zamanı kontrol edebilmelerine yönelik bilgilendirmeler yapılabilir.

4. Üniversitelerde öğrencilerce kullanımı yaygın olan sosyal medyaya kayıtsız kalmayarak, sosyal medya üzerinden eğitimsel, sosyal ve yönetimsel anlamda kolaylıklar sağlayacak uygulamalar öğrencilerin hizmetine sunabilirler.

5. Nitel çalısmalarla gençlerin sosyal medyaya ilişkin tutumları ve sahip oldukları tutumlarının nedenleri ayrıntılı olarak araştırılabilir.

\section{KAYNAKÇA}

Ajjan, H. \& Hartshorne, R. (2008). Investigating faculty decisions to adopt web 2.0 technologies: Theory \& empirical tests. Internet and Higher Education, 11, 71-80.

Akbulut, A. B. \& Y1lmazel, G. (2012). Ergen yas grubunda internet bağımllĭğ düzeyinin belirlenmesi. 15.Ulusal Halk Sağlığ1 Kongresinde sözlü olarak sunulmuştur. Bursa, Uludağ Universitesi.

Akkoyunlu, B. (1999). İnternet'in ögretim sürecinde kullanılması. BITE 1999: Bilişim Teknolojileri Işı̆̆ında Eğitim Konferans1 ve Sergisi Bildiriler Kitabı. (13-15 Mayss 1999). Ankara: Meteksan, 77-82.

Albion, P. R. (2008). Web 2.0 in teacher education: Two imperatives for action. Online: https://eprints.usq.edu.au/4553/1/Albion_Web_2.0_in_teacher_education.pdf

Arg1n, F. S. (2013). Ortaokul ve lise ögrencilerinin sosyal medyaya ilişkein tutumlarmm incelenmesi. (Yayımlanmamış yüksek lisans tezi). YÖK Ulusal Tez Merkezi veri tabanından elde edildi. (Tez no: 327660).

Attwell, G. (2007). Personal learning environments-The future of elearning?. eLearning Papers, 2(1), 1-8. 
Balcı, Ş. \& Gülnar, B. (2009). Üniversite öğrencileri arasında internet bağımlılığ1 ve internet bağımlılığının profili. Selçu Üniversitesi İletisim Fakültesi Akademik Dergisi, 6(1), 5-22.

Baran, B. (2010). Facebook as formal instructional environment. British Journal of Educational Technology, 41(6), 146-149.

Barış, M. F. (2011). Bir sosyal ăg sitesine e-portfolyonun (elektronik gelişim dosyasi) entegre edilerek uygulanması ve sonuclarmm incelenmesi. (Yayımlanmamıs doktora tezi). YÖK Ulusal Tez Merkezi veri tabanından elde edildi. (Tez no: 304652).

Brenner, V. (1997). Psychology of computer use: XLVII. Parameters of Internet use, abuse and addiction: The first 90 days of the Internet usage survey. Psychol. Rep., 80, 879-882.

Cengizhan, C. (2005). Öğrencilerin bilgisayar ve internet kullanımında yeni bir boyut: Bağımlılık. VIII. Ulusal Psikolojik Damısma ve Rebberlik Kongresi. İstanbul, Türkiye. Alınan yer http://mimoza.marmara.edu.tr/ cahit/Yayin/bildiri/PDR2005Bil/PDR2005_Bildiri.pdf

Chou, C., Condron, L. \& Belland, J.C. (2005). A review of the research on internet addiction. Educational Psychology Review, 17(4), 363-388.

Cochran, W.G. (1977). Sampling techniques (3rd ed.). New York: Wiley.

Conole, G., \& Culver J. (2010). The design of cloudworks: Applying social networking practice to foster the exchange of learning and teaching ideas and designs. Computers \& Education, 54, 679692.

Çil, H. (2008). Teknolojinin eğitim ve ögrretim faaliyetlerindeki rolü: Öğretmen adaylarmm görüsleri. (Yayımlanmamış yüksek lisans tezi). YÖK Ulusal Tez Merkezi veri tabanından elde edildi. (Tez no: 220055).

Demirdaş, H. (2001). Eğitimdeki değişimin öğretmen ve teknolojik boyutu. Bilim ve Aklın Aydınhŭgnda Egitim Dergisi, 2(14), 1-3. Alınan yer http://baae.meb.gov.tr/

Dewson, A., Houghton D. \& Patten J. (2008). Blogging and other social media: exploiting the technology and protecting the enterprise. New Jersey: Gower Publishing.

Digital in 2017: Global Overview. (2017). Online: https://wearesocial.com/uk/special-reports/digital-in2017-global-overview

D'souza, Q. (2006). Web 2.0 Ideas For Educators. Online: http://www.teachinghacks.com/audio/100ideas Web2educators.pdf

Duman, A., (1998). İnternet öğrenim ve eğitim üzerine bir deneme. Alınan yer http://www.bilimveutopya.com.tr/

Eijkman, H. (2009). Using web 2.0 to decolonise transcultural learning zones in higher education. Campus-Wide Information Systems, 26(3), 240-255.

Ergenç, A. (2011). Web 2.0 ve sanal sosyalleşme: facebook örneği. (Yayımlanmamış yüksek lisans tezi). YÖK Ulusal Tez Merkezi veri tabanından elde edildi. (Tez no: 278725).

Erzurum, F. \& Tiryakioğlu, F. (2011). Bir eğitim aracı olarak ağlarn kullammı. 2nd International Conference on New Trends in Education and Their Implications. Antalya, Türkiye.

Ferraro, G., Caci, B., D’amico, A. \& Blasi, M.D. (2007). Internet Addiction Disorder: An Italian Study. Cyberpsychology and Behavior. 10(2), 170-175.

Gökçearslan, Ş. (2011). Semantik web (web 3.0) ve eğitim amaçlı kullanımı. Ĕ̈itim Teknolojileri Araştrrma Dergisi, 2, 5-20.

Grant, N. (2008). On the usage of social networking software technologies in distance learning education. In K. McFerrin et al. (Eds.), Proceedings of Society for Information Technology and Teacher Education. International Conference 2008. 3755-3759. Chesapeake, VA: AACE.

Gülbahar, Y., Kalelioğlu, F. \& Madran, R. O. (2010). Sosyal ağlarn eğitim amaçl kullanımı inet-tr Türkiye'de İnternet Konferansı. İstanbul, İstanbul Teknik Üniversitesi.

Gülseçen, S., Gürsul, F., Bayrakdar B., Çilengir, S. \& Canım, S. (2010). Yeni nesil mobil ögrrenme aracı: Podcast. Akademik Bilişim Konferansında sözlü olarak sunulmuştur. Muğla, Muğla Universitesi. Alınan yer http://ab.org.tr/ab11/kitap/_AB11_tek.pdf

Gülsoy, T. (2009). Etkileşimli medya ve pazarlama terimler söəlügü. L. Baruh, ve M. Yüksel içinde, Değişen İletişim Ortamında Etkileşimli Pazarlama. İstanbul: Doğan Kitap.

Horzum, M.B. (2010). Öğretmenlerin web 2.0 araçlarından haberdarlı̆̆ı, kullanım sıklıkları ve amaçlarının çeşitli değişkenler açısından incelenmesi. Uluslararası Insan Bilimleri Dergisi, 7(1), 603-634.

Johnson, D., \& Johnson, R. (2004). Cooperation and the use of technology. In D. Jonassen (Ed.), Handbook of research on educational communications and technology (2nd ed.; pp. 1017-1044). Mahwah, NJ: Erlbaum.

Jones, N., Blackey, H., Fitzgibbon, K., \& Chew, E. (2010). Get out of MySpace!. Computers\&Education, 54, 776-782.

Kandell, J. (1998). Internet addiction on campus-the vulnerability of college students. Cyberpsychology \& Behavior, 1, 46-59.

Kaptan, S. (1998). Bilimsel araștıma ve istatistik teknikleri. Ankara: Tekışık Ofset. 
Karaman, S., Yıldırım, S. \& Kaban A. (2008). Öğrenme 2.0 yaygznlassyor: Web 2.0 uygulamalarmm eğitimde kullammina ilişkin araştırmalar ve sonuçlar. XIII. Türkiye'de İnternet Konferansı Bildirileri. Alınan yer http://inet-tr.org.tr/inetconf13/kitap/karaman_yildirim_inet08.pdf

Karasar, N. (2009). Bilimsel araştırma yöntemleri. (20. Bask1). Ankara: Nobel Yayınları.

Kesselman, M. (2008). Web 2.0 expo in New York: Building online communities. Library Hi Tech News, No. 9.

Lee, M-S., Ko, Y-H., Song, H-S., Kwon, K.-H., Lee, H-S., Nam, M. \& Jung, I-K., (2007). Characteristics of internet use in relation to game genre in Korean adolescents. Cyberpsychology \& Behavior, 10(2), 278-285.

McLoughlin, C., \& Lee, M. J. (2007). Social software and participatory learning: Pedagogical choices with technology affordances in the web 2.0 era. In ICT. Providing choices for learners and learning. Proceedings ascilite Singapore 2007.

Mejias, U. (2010). Social Media in the classroom: Implications for teaching and learning. Georgetown University Scholarly Communication Symposium, Washington DC.

Morahan-Martin, J. M., \& Schumacker, P. (2000). Incidence and correlates of pathological internet use. Computer Human Behaviour, 16, 13-29.

O'Reilly, T. (2005). What Is web 2.0: Design patterns and business models for the next generation of software. Alinan yer http://www.oreilly.com/pub/a/web2/archive/what-is-web-20.html?pag $\% 20 \mathrm{e} \% 20=1$

Otrar, M. \& Argın, F. S. (2015). Öğrencilerin sosyal medyaya ilişkin tutumlarm belirlemeye yönelik bir ölçek geliştirme çalısması. 7. Uluslararası Bilgisayar ve Öğretim Teknolojileri Sempozyumunda (ICITS) sözlü olarak sunulmuştur. Erzurum, Atatürk Üniversitesi. Alınan yer http://www.jret.org

Öztürk, M. (2011). Üniversite ögrencilerinin sosyal paylaşım sitelerini kullanma amaçlar ve eğitimde kullanımuyla ilgili görüsleri. (Yayımlanmamış yüksek lisans tezi). YÖK Ulusal Tez Merkezi veri tabanından elde edildi. (Tez no: 328049).

Pettenati, M. C., \& Ranieri, M. (2006). Informal learning theories and tools to support knowledge management in distributed CoPs. Paper presented at the Innovative Approaches for Learning and Knowledge Sharing, EC-TEL. Workshop Proceeding.

Petter, C., Reich, K., \& Scheuermann, F. (2005). Analysis of tools supporting communities of practice. Work \& Learn Together, 1-14.

Selwyn, N. (2007). Screw blackboard... do it on facebook! an investigation of students' educational use of facebook. Alinan yer http://startrekdigitalliteracy.pbworks.com/f/2g19b89ezl6ursp6e749.pdf

Soule, L. C., Shall, W. \& Kleen, B.A. (2003). Exploring internet addiction: Demographic characteristics and stereotypes of heavy internet users. Journal of Computer Information Systems, Fall, 64-73.

Taylor, P., Parker, K., Lenhart, A. \& Patten, E. (2011). The digital revolution and higher education. Alinan yer http://www.pewsocialtrends.org/files/2011/08/online-learning.pdf

Tekinarslan, E. \& Gürer, M.D. (2011). Abant İzzet Baysal Üniversitesi Böte öğrencilerinin bilgi paylaşımı ve web yayın araçları olarak ağ günlükleri hakkındaki görüşleri. Kastamonu Ë̆itim Dergisi, 19(3), 887-902.

Tektaş, N. (2014). Üniversite ğğrencilerinin sosyal ağları kullanımlarına yönelik bir araştırma. Tarib Okulu Dergisi (TOD), XVII, 851-870.

Turnalar Kurtaran, G. (2008). İnternet bağımlihğın yordayan değ̈̆skenlerin incelenmesi. (Yayımlanmamış yüksek lisans tezi). YÖK Ulusal Tez Merkezi veri tabanından elde edildi. (Tez no: 227399).

Uysal, S. (2013). Meslek lisesi ögrrencilerinin sosyal medya kullanm amaçlar ile eğitsel sosyal medya kullanımlarmm değerlendirilmesi. (Yayımlanmamış yüksek lisans tezi). YÖK Ulusal Tez Merkezi veri tabanından elde edildi. (Tez no: 365623).

Yamamoto G. T., Demiray, U. ve Kesim, M. (2010). Türkiye'de e-ögrenme: gelismeler ve uygulamalar. Ankara: Cem Web Ofset.

Young, K. S. (1998) Center for internet addiction. İnternet addiction test (IAT). Alinan yer http://www.netaddiction.com/resources/internet_addiction_test.htm

Yuen, S. \& Yuen, P. (2008). Social networks in education. In G. Richards (Eds.), Proceedings of World Conference on E-Learning in Corporate. Government, Healthcare, and Higher Education, Chesapeake, VA: AACE, 1408-1412.

Ziegler, S. G. (2007). The (Mis) education of generation M. Learning. Media and Technology, 32(1), 69-81.

\section{Citation Information}

Aküzüm, C. \& Saraçoğlu, M. (2017). Üniversite Öğrencilerinin Sosyal Medyaya İlişkin Tutumlarının İncelenmesi. Dicle Üniversitesi Ziya Gökalp Eğitim Fakültesi Dergisi, 32, 803-817. 